\title{
Uterine oxytocin receptors in cyclic and pregnant cows
}

\author{
L. J. Jenner $\dagger$, T. J. Parkinson* and G. E. Lamming
}

AFRC Research Group on Hormones and Farm Animal Reproduction, University of Nottingham Faculty of Agricultural and Food Sciences, Sutton Bonington, Loughborough, Leics LE12 5RD, UK

\begin{abstract}
Summary. Binding of $\left[{ }^{3} \mathrm{H}\right]$ oxytocin to uterine subcellular preparations ('oxytocin receptor concentrations') was measured in uterine tissue of heifers and multiparous dairy cows at various stages of the oestrous cycle and during early pregnancy. A method for the assay of ovine uterine oxytocin receptors was optimized for use on bovine tissue. Oxytocin receptor concentrations were increased in cyclic animals around the period of luteolysis and oestrus, rising on Day 15 in endometrium and on Day 17 in myometrium while pregnant animals showed no comparable rise. Receptor concentrations then declined on Day 3 after oestrus in myometrium and on Day 5 in endometrium. Some cyclic animals did not show the expected rise in receptors in the late luteal phase; these animals had abnormally high progesterone concentrations for this stage of the cycle. In animals slaughtered on Day 18 after oestrus and/or insemination which had low oxytocin receptor levels, plasma progesterone concentrations were consistently high; while all animals showing the late luteal phase elevation in receptor values had low progesterone concentrations. Oxytocin receptor and progesterone concentrations were negatively correlated $(P<0.05)$. These data support the hypothesis that oxytocin receptor level is a key factor in the process of luteolysis in cattle and that in pregnancy there is suppression of uterine oxytocin receptor at the expected time of luteolysis. We suggest that uterine oxytocin receptor levels are partly controlled by circulating steroid hormones and are suppressed during early pregnancy.
\end{abstract}

Keywords: uterus; oxytocin; receptors; cattle; oestrous cycle; pregnancy

\section{Introduction}

The secretion of oxytocin and the presence of oxytocin receptors in the uterus is considered important in controlling the episodic patterns of prostaglandin (PG)F-2 $\alpha$ responsible for luteolysis in the ruminant animal (Flint \& Sheldrick, 1983; McCracken et al., 1984). Oxytocin receptors have been characterized in the uterus of the rat and sow (Soloff \& Swartz, 1974), guinea-pig (Alexandrova \& Soloff, 1980), human (Fuchs et al., 1982), sheep (Roberts et al., 1976; Crankshaw et al., 1982; Sheldrick \& Flint, 1985) and cow (Schams, 1987; Meyer et al., 1988; Soloff \& Fields, 1989). The amount of oxytocin binding to uterine components shows distinct cyclic changes in the ewe, being maximal at the time of luteolysis, then declining in the early luteal phase (Sheldrick \& Flint, 1985). This coincides with the time of maximal responsiveness of both myometrium and endometrium to oxytocin stimulation (Roberts et al., 1976). The levels then decline, reaching basal values early in the luteal phase, before which (Day 5) systemically applied oxytocin has a luteolytic effect in the cow (Armstrong \& Hansel, 1959; Anderson et al., 1965; Ginther et al., 1967). However, luteal oxytocin concentrations are highest in the early-mid luteal phase, and decline in the late luteal

\footnotetext{
*Present address: Department of Veterinary Surgery, University of Bristol, Langford House, Langford, Bristol BS18 7DU, UK.

†Present address: Department of Immunopathology, AFRC Institute for Animal Health, Compton, Berks RGI6 0NN, UK.
} 
phase, reaching a nadir at the time of oestrus (Wathes et al., 1984). This suggests that the PGF-2 $\alpha$ response to peaks of oxytocin at the time of luteolysis is regulated by uterine oxytocin receptor concentrations.

Thus, because uterine oxytocin receptors appear to be the key to the initiation of luteolysis in ruminants, this study investigated the binding of oxytocin to both endometrial and myometrial tissues throughout the cycle and on the relevant days of early pregnancy. The correlation of oxytocin receptor concentration with circulating steroid concentrations was also examined.

\section{Materials and Methods}

\section{Animals}

Uteri were collected from Holstein $\times$ Hereford and South Devon heifers whose oestrous cycles were synchronized using a single intramuscular injection of $500 \mathrm{mg}$ cloprostenol (Estrumate: Coopers Animal Health Ltd, Crewe, UK). Oestrus, as detected by mounting behaviour, occurred $72-96 \mathrm{~h}$ after the administration of cloprostenol. Daily blood samples were taken from the day of synchronization by venepuncture for determination of progesterone profiles. Day 0 was considered to be the day on which progesterone concentrations were at their lowest. In addition, uteri were collected from multiparous cows obtained from the University dairy herd. In this case, cows were monitored by twicedaily observation for signs of behavioural oestrus and collection of daily milk samples for progesterone measurement. Cows were then slaughtered on a specified day of the cycle to allow collection of the reproductive tract. Tissue from cyclic animals was collected on Day 0 (oestrus; $N=9)$, Day $1(\mathrm{~N}=2)$, Day $2(\mathrm{~N}=1)$, Day $3(\mathrm{~N}=2)$, Day $4(\mathrm{~N}=$ 1), Day $5(\mathrm{~N}=3)$, Day $6(\mathrm{~N}=2)$, Day $8(\mathrm{~N}=1)$, Day $9(\mathrm{~N}=3)$, Day $12(\mathrm{~N}=3)$, Day $15(\mathrm{~N}=3)$, Day $16(\mathrm{~N}=7)$, Day $17(\mathrm{~N}=3)$ and Day $18(\mathrm{~N}=10)$.

For the collection of tissue from pregnant animals, oestrus was similarly induced in heifers and animals were inseminated on the day of oestrus and slaughtered on a specified day of pregnancy. For multiparous cows, insemination occurred on the day of natural oestrus as detected by the herdsman. Plasma samples from heifers and milk samples from cows were collected as described for cyclic animals. The uteri were flushed with $20 \mathrm{ml}$ saline $(0.9 \%$ : Baxter Health Care, Thetford, Norfolk, UK) within $10 \mathrm{~min}$ of slaughter to confirm the presence of an embryo. Animals which had no embryo were described as 'inseminated non-pregnant' (INP). Tissue from pregnant animals was collected on Day $5(\mathrm{~N}=1)$, Day $7(\mathrm{~N}=2)$, Day $8(\mathrm{~N}=1)$, Day $12(\mathrm{~N}=5)$, Day $13(\mathrm{~N}=3)$, Day $15(\mathrm{~N}=1)$, Day $16(\mathrm{~N}=2)$, Day $18(\mathrm{~N}=9)$, Day $19(\mathrm{~N}=4)$, Day $20(\mathrm{~N}=1)$ and Day $22(\mathrm{~N}=2)$. Tissue from INP cows was collected on Day $6(N=1)$, Day $7(N=1)$, Day $8(N=4)$, Day $9(N=2)$, Day $10(N=1)$, Day $12(N=3)$, Day 18 $(\mathrm{N}=3)$, Day $19(\mathrm{~N}=6)$ and Day $20(\mathrm{~N}=2)$.

\section{Measurement of $\left.\right|^{3} \mathrm{H} \mid \mathrm{oxy}$ tocin binding to uterine preparations}

Uteri were collected onto ice immediately after slaughter and dissected in the laboratory within $10 \mathrm{~min}$. Subcellular fractions of endometrium and myometrium were prepared by the method of Sheldrick \& Flint (1985). The pellets obtained after ultracentrifugation at $90000 \mathrm{~g}$ were resuspended in $25 \mathrm{mM}-\mathrm{Tris}-\mathrm{HCl}(\mathrm{pH} 7 \cdot 6)$ using a Polytron homogenizer. This suspension was stored at $-196^{\circ} \mathrm{C}$ until assay. Protein concentrations in the preparations were determined by the method of Lowry et al. (1951), using bovine serum albumin standards. To measure oxytocin binding, the method established by Sheldrick \& Flint (1985) for sheep preparations was optimized for use with bovine tissue by examining several variables. All optimization investigations were carried out using subcellular fractions prepared from the uteri of cows on the day of oestrus (Day 0 ).

Time and temperature of incubation. Figure 1(a) shows the effect of time and temperature of incubation on the amount of $\left[{ }^{3} \mathrm{H}\right]$ oxytocin bound to the subcellular preparation. From this, an incubation period of $20 \mathrm{~min}$ at $20^{\circ} \mathrm{C}$ was chosen as the optimal time and temperature at which to obtain maximal binding.

Non-specific binding. Increasing concentrations of unlabelled oxytocin were added to the assay tubes to follow displacement of the labelled oxytocin. Concentrations of $0,1,10,100$ and $1000 \mathrm{ng}$ oxytocin gave binding values of $770.03 \pm 16 \cdot 3,244 \cdot 30 \pm 10 \cdot 05,116 \cdot 50 \pm 10 \cdot 36,93.63 \pm 3.78$ and $113.93 \pm 11.67 \mathrm{fmol}$ oxytocin bound $/ \mathrm{mg}$ protein, respectively. Thus $100 \mathrm{ng}$ oxytocin was sufficient to cause maximum displacement of labelled oxytocin. Any residual binding (i.e. $116.50 \mathrm{fmol} / \mathrm{mg}$ protein) was assumed to be non-specific and not due to the presence of oxytocin receptors. Concentrations below this point were added to the assay to construct a Scatchard plot (Scatchard, 1949) in the presence of $2.5 \mathrm{nM}-\left[{ }^{3} \mathrm{H}\right]$ oxytocin. This allowed the determination of a dissociation constant $\left(K_{\mathrm{d}}\right)$ value of $1.88 \mathrm{nM}$.

Addition of cations. In the sheep oxytocin receptor assay, $\mathrm{Mn}^{2+}$ ions are added in the form of $\mathrm{MnCl}_{2}$ to enhance receptor binding. In the bovine assay the addition of $\mathrm{MnCl}_{2}$ did not enhance binding. However, $\mathrm{Mg}^{2+}$ ions did enhance binding, with concentrations of $0,0.1,1.0$ and $10.0 \mathrm{~mm}-\mathrm{MgCl}_{2}$ in the assay giving binding values of $895 \cdot 0 \pm 2 \cdot 6,1048 \cdot 0 \pm 14 \cdot 5,1101 \cdot 0 \pm 40 \cdot 3$ and $1120 \cdot 0 \pm 105 \cdot 0 \mathrm{fmol}$ oxytocin bound/mg protein, respectively. Significant increases in binding $(P<0.001)$ were obtained when the concentration of $\mathrm{MgCl}_{2}$ was increased from 0 to 

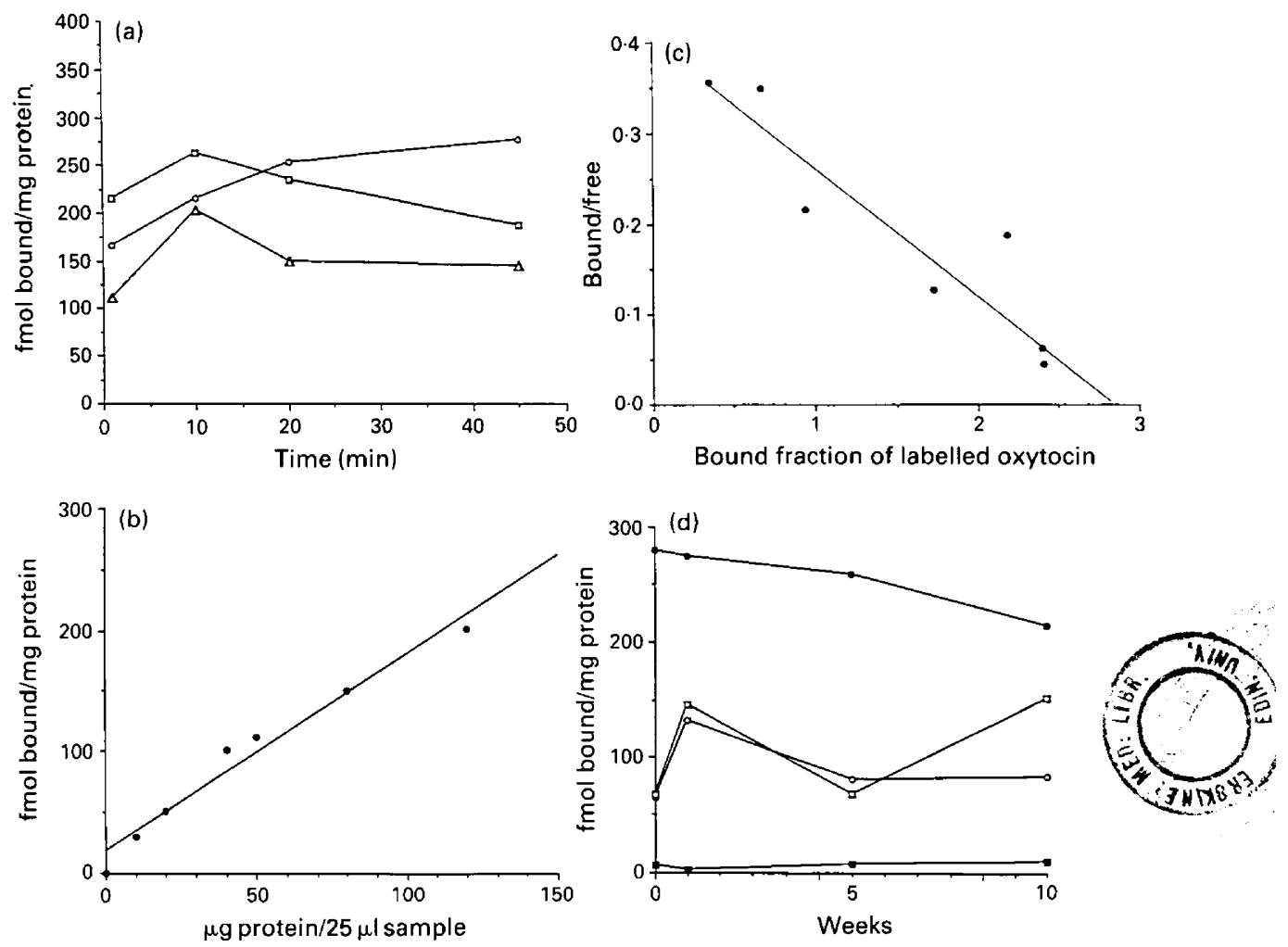

Fig. 1. Optimization of assay conditions for bovine uterine oxytocin receptors. (a) The effect of time and temperature of incubation on $\left[{ }^{3} \mathrm{H}\right]$ oxytocin binding. $O=20^{\circ} \mathrm{C} ; \square=25^{\circ} \mathrm{C} ; \triangle=$ $30^{\circ} \mathrm{C}$. (b) The effect of protein concentration in the sample on the binding of $\left[{ }^{3} \mathrm{H}\right]$ oxytocin. (c) A representative Scatchard plot using increasing concentrations of $\left[{ }^{3} \mathrm{H}\right]$ oxytocin. (d) Effect of storing tissue at $-196^{\circ} \mathrm{C}$ for $0,1,6$ or 12 weeks before preparation of subcellular fractions. $\mathbf{\square}=$ pregnant endometrium; $\square=$ pregnant myometrium; $=$ cyclic endometrium; $O=$ cyclic myometrium.

$0.1 \mathrm{~mm}$ and from 0.1 to $1.0 \mathrm{mM}$, but not when the concentration was increased further. Therefore, a concentration of $1.0 \mathrm{mM}-\mathrm{MgCl}_{2}$ was selected as causing optimal binding.

Protein concentration per tube. Because samples contained various concentrations of protein, samples were assayed using different concentrations of membrane protein. Figure 1(b) shows that a linear relationship exists between protein concentration and oxytocin binding. However, all samples were routinely diluted to obtain approximately $50 \mu \mathrm{g}$ protein per $25 \mu \mathrm{l}$ before use in the assay to standardize the procedure.

Effect of label concentration on binding of I $^{3} \mathrm{H}$ Joxytocin to receptors. A Scatchard plot was constructed by adding increasing concentrations of labelled oxytocin $\left(\left[{ }^{3} \mathrm{H}\right]\right.$ oxytocin) to the assay (Fig. 1c). This allowed the determination of a $K_{\mathrm{d}}$ of $1.37 \mathrm{~nm}$. Although some scatter is evident, repeated trials have not yielded a closer relationship.

Storage of non-prepared tissue. Tissue was collected from 7 heifers on Day 18 after oestrus (3 cyclic, 3 pregnant and 1 inseminated non-pregnant). One part of each uterus was used immediately for the preparation of subcellular fractions, and the remaining tissue was frozen at $-196^{\circ} \mathrm{C}$ and used 1,6 and 12 weeks later for the preparation of subcellular fractions. Figure 1(d) shows that there was some variation in the level of oxytocin binding to the preparation over the 12 weeks. Regardless of whether the variation was of a significant level, it was decided that fractions should be prepared immediately after slaughter to minimize any variation caused by storage time.

\section{Modified assay for bovine tissue}

For routine assay $50 \mu \mathrm{g}$ protein were incubated at $20^{\circ} \mathrm{C}$ for $20 \mathrm{~min}$ in $0.1 \mathrm{ml}$ Tris- $\mathrm{HCl}(25 \mathrm{~mm}, \mathrm{pH} 7.6)$, containing $0.1 \%$ bovine serum albumin (Tris-BSA), $1 \mathrm{~mm}-\mathrm{MnCl}_{2}$ and $2 \cdot 5 \mathrm{~nm}-\left[3,5-{ }^{3} \mathrm{H}-\mathrm{Tyr}\right]$ oxytocin (sp. act. $36 \cdot 6 \mathrm{Ci} / \mathrm{mmol}$; NEN Dupont, Dreierch, West Germany). Non-specific binding was measured in the presence of $100 \mathrm{ng}$ unlabelled oxytocin 
(Bachem Ltd, Torrance, CA, USA). Scintillation counting was carried out with an efficiency of $60 \%$ (Packard Instruments model 1900CA). Inter- and intra-assay coefficients of variation for measurement of receptor concentrations were $16.0 \%$ and $9.3 \%$ respectively. The sensitivity of the assay was $69.5 \mathrm{fmol} / \mathrm{mg}$ protein, and $50 \%$ displacement of tracer occurred between 0.5 and $1.0 \mathrm{pmol} /$ tube. Binding of $\left[{ }^{3} \mathrm{H}\right]$ oxytocin to the filters (GVWP filters, pore size $0.22 \mathrm{~mm}$, Millipore, Watford, Herts, UK) in the absence of uterine extract was $0.18 \%$. Oxytocin binding was expressed as fmol oxytocin bound $/ \mathrm{mg}$ protein. $K_{\mathrm{d}}$ values obtained from the receptor were $1.37 \mathrm{~nm}$ when calculated by adding increasing concentrations of $\left[{ }^{3} \mathrm{H}\right]$ oxytocin to the assay, and $1.88 \mathrm{~nm}$ when calculated by displacement of $\left[{ }^{3} \mathrm{H}\right]$ oxytocin by increasing concentrations of unlabelled oxytocin.

\section{Radioimmunoassay of progesterone}

Progesterone was measured in duplicate $100 \mathrm{ml}$ plasma samples as described by Haresign et al. (1975) and modified by Hunter $e t$ al. (1986). Samples were randomized throughout each assay. The inter- and intra-assay coefficients of variation were $<15 \%$ and $<10 \%$ respectively. The limit of sensitivity was $0.23 \mathrm{ng} / \mathrm{ml}$. Milk progesterone concentrations were determined as described by Gadsby et al. (1974) and modified by Bulman \& Lamming (1978). Inter- and intra-assay coefficients of variation were $<20 \%$ and $9 \%$ respectively, and the limit of sensitivity was $2 \mathrm{ng} / \mathrm{ml}$.

\section{Statistical analysis}

The results were analysed using GENSTAT on the University of Nottingham VME computer. Oxytocin receptor profiles were analysed by a linear regression of oxytocin receptors upon Day combined with the progesterone concentrations on the day of slaughter. This was followed by an analysis of variance across day of cycle or pregnancy and reproductive status. Differences between cyclic, pregnant and inseminated non-pregnant animals on Days 12 and 18 were tested by Student's $t$ test.

\section{Results}

Binding of $\left[{ }^{3} \mathrm{H}\right]$ oxytocin to uterine membranes ('oxytocin receptor concentration') measured in cyclic cows is shown in Fig. 2(a) while Fig. 2(b) shows the data collected from pregnant cows. Concentrations were significantly higher at the time of luteolysis in cyclic cows than at the corresponding time in pregnant cows $(P<0.05)$. Figure 2(c) shows the data collected from inseminated non-pregnant cows. Data for all cyclic cows which had abnormally high progesterone concentrations for the late luteal phase, and did not show high receptor levels at this time are shown in Fig. 2(d).

In cyclic animals oxytocin binding in endometrial tissues began to rise at Day 15 after oestrus, while myometrial binding did not begin to rise until Day 17. Binding in both tissues then remained high until Day 3 after oestrus in myometrium and Day 5 in endometrium.

The regression of oxytocin receptor concentrations in the endometrium upon day showed a quadratic relationship with the nadir occurring on Day $9(P<0.05$; Fig. 2a). When plasma progesterone concentrations were combined with the effect of day, a significantly greater proportion of the variance in these receptor data was accounted for $(P<0.05)$ such that progesterone concentrations were negatively correlated with oxytocin receptor concentrations.

On Day 18 after oestrus there was a distinct difference between pregnant and cyclic animals in terms of both oxytocin receptor binding and progesterone concentrations although, again, some of the non-pregnant animals showed abnormal progesterone concentrations and corresponding low levels of oxytocin receptors (Table 1).

\section{Discussion}

These results show that uterine oxytocin binding through the bovine oestrous cycle follows a pattern similar to that reported for the sheep (Sheldrick \& Flint, 1985), with endometrial levels generally exceeding those in myometrial tissue (Roberts et al., 1976; Sheldrick \& Flint, 1985) and highest at luteolysis, coinciding with the withdrawal of progesterone from the circulation. This is consistent with the hypothesis proposed by Vallet et al. (1990) that receptor levels are influenced by 


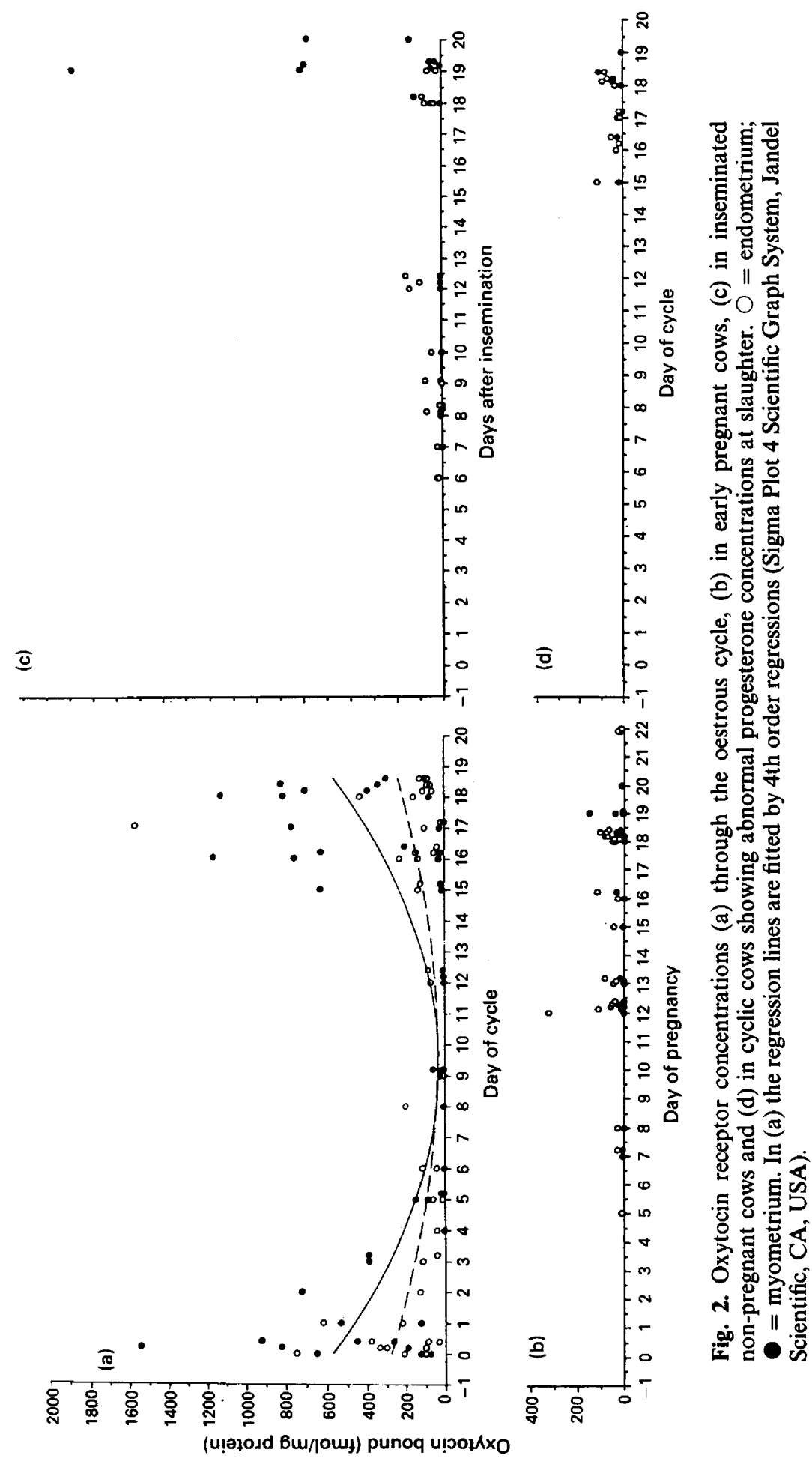


Table 1. Mean \pm s.e.m. oxytocin receptor concentrations ( $\mathrm{fmol} / \mathrm{mg}$ protein) in endometrial and myometrial tissue, and plasma progesterone concentrations on Day 18, in cyclic and pregnant cows, and in cyclic cows which still have high plasma progesterone concentrations

\begin{tabular}{lccc}
\hline & Cyclic & Pregnant & $\begin{array}{c}\text { High } \\
\text { progesterone } \dagger\end{array}$ \\
\hline Oxytocin receptors & & & \\
$\quad$ Endometrium & $563 \cdot 4 \pm 117$ & $18 \cdot 1 \pm 4 \cdot 6^{*}$ & $52 \cdot 3 \pm 23 \cdot 4^{*}$ \\
$\quad$ Myometrium & $82 \cdot 3 \pm 9 \cdot 8$ & $75 \cdot 3 \pm 7 \cdot 7$ & $71 \cdot 9 \pm 13 \cdot 8$ \\
Progesterone & $0.93 \pm 0.4$ & $8 \cdot 37 \pm 0 \cdot 7^{*}$ & $10 \cdot 5 \pm 1 \cdot 1^{*}$ \\
$\quad(\mathrm{ng} / \mathrm{ml})$ & 4 & 6 & 4 \\
No. of cows & 4 & 6 & 4 \\
\hline
\end{tabular}

*Significantly different from cyclic animals $(P<0.05)$.

fOf these 4 animals, 3 were inseminated non-pregnant. The cyclic animal had values of $\mathbf{4 5} \cdot 9,97 \cdot 4$ and $\mathbf{9 \cdot 5}$ for endometrial and myometrial oxytocin receptors and progesterone concentrations, respectively.

circulating steroid concentrations, being initially suppressed and later stimulated by progesterone. The subsequent rise in uterine oxytocin receptor concentrations therefore causes luteolysis, thus bringing about the eventual decline in luteal progesterone production. It has been postulated that luteal phase progesterone inhibits receptor formation (Soloff, 1975; Nissenson et al., 1978; Sheldrick \& Flint, 1985). However, the precise interaction between ovarian steroid hormones and the presence of uterine oxytocin receptors remains to be defined. The present study confirms that cows with uncharacteristically low oxytocin receptor levels for the late luteal phase have correspondingly high plasma progesterone values. McCracken et al. (1984) showed that oestradiol induces oxytocin receptor formation in ewes, while the results of Parkinson et al. (1990) also show a positive correlation between plasma oestradiol concentrations and uterine oxytocin receptor levels, along with a negative correlation between plasma progesterone and uterine oxytocin receptor concentrations. One possible explanation could be that oxytocin receptor formation is influenced by the preovulatory oestradiol rise, and the interaction of oxytocin with the uterine receptors induces PGF-2 $\alpha$ release and brings about luteolysis and thus a decline in progesterone concentrations. The alternative preferred explanation is that progesterone eventually loses its inhibitory effect on uterine oxytocin receptors.

There appears to be a slight rise in oxytocin receptor values in the myometrium on Day 12 after oestrus in pregnant and inseminated non-pregnant cows compared to cyclic cows in which mean oxytocin binding on Day 12 is below the limit of sensitivity of the assay. A small but significant depression of progesterone concentrations occurs in mated but subsequently non-pregnant cows on Day 12 after mating (Lamming et al., 1989). The small change in ratio of progesterone to oestradiol concentrations in such animals may be sufficient to allow the development of myometrial oxytocin receptors, and be responsible for the small episodes of PGF-2 $\alpha$ release shown in pregnant and non-pregnant cows about 12 days after ovulation (Parkinson \& Lamming, 1990).

Administration of oxytocin early in the cycle brings about luteolysis in cattle (Armstrong \& Hansel, 1959; Anderson et al., 1965; Ginther et al., 1967), which can be prevented by hysterectomy (Armstrong \& Hansel, 1959). Such infusions of oxytocin on Days 2 and 3 of the cycle cause increased peripheral PGFM concentrations (Oyedipe et al. 1984), and oxytocin administration at this time therefore causes premature luteolysis by stimulating PGF- $2 \alpha$ production. The present results confirm that this occurs due to the continued presence of elevated amounts of oxytocin receptor in the myometrium until Day 3 and in the endometrium until Day 5 of the new cycle. Furthermore, these results on the temporal changes in uterine oxytocin receptor levels probably explain previous reports of the effects of oxytocin infusion in the mid-late luteal phase on PGFM levels and cycle length extension in cows. Kotwica et al. (1988) showed that infusion of oxytocin 
beginning on Day 14,15 or 16 in cyclic animals resulted in a plasma PGFM response and no extension of cycle length, whereas Gilbert et al. (1989) infused oxytocin from Day 10 after oestrus and obtained no PGFM response and a significant extension of cycle length. This would suggest that the bovine uterus becomes susceptible to oxytocin between Day 10 and Day 14 of the cycle, the presence of oxytocin before this time possibly causes a down-regulation of the oxytocin receptor (Flint \& Sheldrick, 1985), and this could explain the results of Lamming et al. (1989).

Luteolysis in the non-pregnant animal is caused by the episodic release of PGF- $2 \alpha$ from the uterus in a positive feedback loop involving oxytocin release from the corpus luteum (Flint $\&$ Sheldrick, 1983), although the process by which this loop is initiated is not yet clear. Circulating oxytocin concentrations in bovine plasma are highest in the mid-luteal phase (Schams et al., 1985), corresponding to the oxytocin content of the corpus luteum at this time. In the cow a decline in luteal oxytocin concentration precedes luteolysis (Wathes et al., 1984), which suggests that the response to oxytocin during the process of luteolysis is regulated by oxytocin receptor levels, rather than by circulating oxytocin concentrations. This suggestion is supported by the fact that changes in oxytocin receptor levels in endometrium and myometrium correlate well with alterations in the responsiveness of these tissues to oxytocin stimulation. Maximal responsiveness of the endometrium to oxytocin in terms of PGF-2 $\alpha$ secretion occurs on Day 15 in cyclic ewes (Roberts et al., 1976), while the maximum luteolytic effect of oxytocin in cows occurs early in the cycle (up to Day 5; Armstrong \& Hansel, 1959) and at the end of the cycle (Day 15 onwards; McCracken et al., 1984) when receptor concentrations are at their highest.

Table 2. Dissociation constants $(K \mathrm{~d}, \mathrm{nM})$ for uterine oxytocin receptors reported in the literature for sheep and cows

\begin{tabular}{|c|c|c|c|}
\hline Species & Authors & Endometrium & Myometrium \\
\hline Sheep & $\begin{array}{l}\text { Roberts et al. (1976) } \\
\text { Crankshaw et al. (1982) } \\
\text { Pliska et al. (1984) } \\
\text { Sheldrick \& Flint (1985) }\end{array}$ & $\begin{array}{c}\text { (range } 0.5-0.7 \text { ) } \\
= \\
\text { (a) } 1.96 \\
\text { (b) } 1.87\end{array}$ & $\begin{array}{c}1 \cdot 8 \pm 0 \cdot 2 \\
1 \cdot 0,50,>10^{-4} \\
2 \cdot 19\end{array}$ \\
\hline Cattle & $\begin{array}{l}\text { Kotwica et al. (1988) } \\
\text { Meyer et al. (1988) } \\
\text { Soloff \& Fields (1989) } \\
\text { Present study }\end{array}$ & $\begin{array}{c}\text { (c) } 1.74 \\
\text { (d) } 1.30 \\
1.83 \pm 0.59 \\
14.9 \pm 3 \cdot 2 \\
\text { (range } 1.3-25 \cdot 7 \text { ) } \\
\text { (e) } 1.37\end{array}$ & $\begin{array}{c}1 \cdot 2 \pm 0 \cdot 16 \\
-\end{array}$ \\
\hline
\end{tabular}

(a) Measured in caruncular tissue; (b) measured in inter-caruncular tissue; (c) measured in tissue taken on Day 21 of the oestrous cycle; (d) measured in tissue taken on Day 1 of the cycle; (e) measured by increasing $\left[{ }^{3} \mathrm{H}\right]$-oxytocin concentration; (f) measured by increasing unlabelled oxytocin concentration.

The oxytocin content of the ovine corpus luteum and, consequently, circulating concentrations of oxytocin decline in early pregnancy (Sheldrick \& Flint, 1983). This has been suggested to be one way in which the endocrine environment of the mother is adapted to pregnancy (Sheldrick \& Flint, 1983; Schams \& Lahlou-Kassi, 1984). A similar reduction in the concentration of the oxytocin prohormone mRNA occurs at the same time in sheep (Jones \& Flint, 1988) and in cows (Ivell et al., 1985). Oxytocin receptor levels in pregnant ewes are low at the expected time of luteolysis (Sheldrick \& Flint, 1985), and the present study has demonstrated that this also occurs in the cow. It has been suggested that maintaining oxytocin receptors at a low level in pregnancy may be a way in which uterine responsiveness to oxytocin is reduced, in order to ensure a decreased uterine secretion of PGF-2 $\alpha$ at this time (Sheldrick \& Flint, 1985; Flint \& Sheldrick, 1986), and hence the maintenance of high progesterone levels necessary for pregnancy. The process by which luteolysis is 
blocked depends upon the presence of an embryo and its production of a trophoblastic interferon (tIFN) (Godkin et al., 1984; Vallet et al., 1988). However, the mechanism by which oxytocin receptor levels are prevented from rising by tIFN is uncertain. In sheep it is possible that this antiluteolytic effect depends upon blastocyst production of tIFN shown to be an $\alpha 2$-interferon (Stewart et al., 1987; Imawaka et al., 1987), the properties of which are under investigation (Stewart et al., 1989). The presence of a similar trophoblastic protein, bTP-1, is being investigated in cows (Bazer et al., 1986; Godkin et al., 1988; Helmer et al., 1989). Another possibility is blastocyst production of oxytocin, which may down-regulate receptor levels in a manner similar to that observed following continuous oxytocin administration to ewes (Flint \& Sheldrick, 1985; Sheldrick \& Flint, 1987). There is conflicting evidence as to whether the ovine conceptus contains or secretes oxytocin (see Flint et al., 1989) or that intrauterine infusion of oxytocin blocks oxytocin receptor formation (unpublished data). However, systemic infusion of oxytocin can block luteolysis in cows if administered beginning on Day 10 (Gilbert et al., 1989).

From previous reports in cows and ewes it appears to have been consistently difficult to calculate precise dissociation constants for the receptor (see Table 2). Pliska et al. (1984) reported multiple binding sites in ovine myometrium while Soloff \& Fields (1989) failed to obtain a consistent Scatchard plot for bovine endometrium, and have published a range of values for $K_{\mathrm{d}}$. Kotwica et al. (1988) published different values for $K_{\mathrm{d}}$ depending on the stage of the cycle, suggesting that the affinity of the receptor changes through the cycle. Meyer et al. (1988) reported a $K_{\mathrm{d}}$ value for bovine endometrium which is very similar to the values found here, and showed that $\left[{ }^{3} \mathrm{H}\right]$ oxytocin binding to the endometrium occurs from Day 17 to Day 6, and is maximal on the day of oestrus.

In conclusion the close correlation between progesterone and endometrial oxytocin receptor concentrations illustrates that the rise in endometrial oxytocin receptor levels is likely to be important in the initiation of luteolysis. This therefore adds evidence to the hypothesis that uterine oxytocin receptor concentrations are important in the process of luteolysis in the cow, and the prevention of the uterine rise in uterine oxytocin receptors is important in the maternal recognition of pregnancy and the maintenance of pregnancy. In the cyclic cow oxytocin receptor levels are closely correlated to the steroid environment, a situation modified in the pregnant animal by the appearance and activity of tIFN.

We thank Professor A. P. F. Flint for help in the preparation of this manuscript and Dr E. L. Sheldrick and Mrs K. E. Clarke for assistance in setting up the oxytocin receptor assay at Sutton Bonington and optimising it for use with bovine tissue. L.J.J. is in receipt of an MAFF studentship.

\section{References}

Alexandrova, M. \& Soloff, M.S. (1980) Oxytocin receptors and parturition in the guinea-pig. Biol. Reprod. 22, $1106-1111$.

Anderson, L.L., Bowerman, A.M. \& Melampy, R.M. (1965) Oxytocin on ovarian function in cycling and hysterectomized heifers. J. Anim. Sci. 24, 965-968.

Armstrong, D.T. \& Hansel, W. (1959) Alteration of the bovine estrous cycle with oxytocin. J. Dairy Sci. 42, 533-542.

Bazer, F.W., Vallet, J.L., Roberts, R.M., Sharp, P.C. \& Thatcher, W.W. (1986) Role of conceptus secretory products in establishment of pregnancy. J. Reprod. Fert. 76, 841-850.

Bulman, D.C. \& Lamming, G.E. (1978) Milk progesterone levels in relation to conception, repeat breeding and factors influencing acyclicity in dairy cows. $J$. Reprod. Fert. 54, 447-458.
Crankshaw, D.J., Romanuik, E. \& Branda, L.A. (1982) Identification and characterisation of receptors for oxytocin in the myometrium of the pregnant ewe. Gynec. Obstet. Invest. 14, 202-213.

Flint, A.P.F. \& Sheldrick, E.L. (1983) Evidence for a systemic role for ovarian oxytocin in luteal regression in sheep. J. Reprod. Fert. 67, 215-225.

Flint, A.P.F. \& Sheldrick, E.L. (1985) Continuous infusion of oxytocin prevents induction of uterine oxytocin receptor and blocks luteal regression in cyclic ewes. J. Reprod. Fert. 75, 623-631.

Flint, A.P.F. \& Sheldrick, E.L. (1986) Ovarian oxytocin and the maternal recognition of pregnancy. J. Reprod. Fert. 76, 831-839.

Flint, A.P.F., Sheldrick, E.L., Jones, D.S.C. \& Auletta, F.J. (1989) Adaptations to pregnancy in the interactions between luteal oxytocin and the 
uterus in ruminants. J. Reprod. Fert., Suppl. 37, 195-204.

Fuchs, A.-R., Fuchs, F., Husslein, P., Soloff, M.S. \& Fernstrom, M.J. (1982) Oxytocin receptors and human parturition: a dual role for oxytocin receptors in the initiation of labour. Science, $N Y 215,1396-1398$.

Gadsby, J.E., Heap, R.B., Henville, A. \& Laing, J.A. (1974) A semi-automated technique for the extraction of progesterone in cows milk and its application to pregnancy diagnosis. J. Physiol., Lond. 242, 3P-5P.

Gilbert, C.L., Lamming, G.E., Parkinson, T.J., Flint, A.P.F. \& Wathes, D.C. (1989) Oxytocin infusion from Day 10 after oestrus extends the luteal phase in non-pregnant cattle. J. Reprod. Fert. 86, 203-210.

Ginther, O.J., Woody, C.O., Mahajan, S., Janakiraman, K. \& Casida, L.E. (1967) Effect of oxytocin administration on the oestrous cycle of unilaterally hysterectomised heifers. J. Reprod. Fert. 14, 225-229.

Godkin, J.D., Bazer, F.W., Thatcher, W.W. \& Roberts, R.M. (1984) Proteins released by cultured D15-16 conceptuses prolong luteal maintenance when introduced into the uterine lumen of cyclic ewes. $J$. Reprod. Fert. 71, 57-64.

Godkin, J.D., Lifsey, B.J. Jr, \& Gillespie, B.E. (1988) Characterization of bovine conceptus proteins produced during the peri- and post-attachment periods of early pregnancy. Biol. Reprod. 38, 703-7I1.

Haresign, W., Foster, J.P., Haynes, N.B., Crighton, D.B. \& Lamming, G.E. (1975) Progesterone levels following treatment of seasonally anoestrous ewes with synthetic LH-releasing hormone. J. Reprod. Fert. 43, 269-279.

Helmer, S.D., Hansen, P.J., Thatcher, W.W., Johnson, J.W. \& Bazer, F.W. (1989) Intrauterine infusion of highly enriched bovine trophoblastic protein-1 complex exerts an antiluteolytic effect to extend corpus luteum lifespan in cyclic cattle. $J$. Reprod. Fert. 87, $89-101$.

Hunter, M.G., Southee, J.A., McLeod, B.J. \& Haresign, W. (1986) Progesterone pretreatment has a direct effect on GnRH-induced preovulatory follicles to determine their ability to develop into normal corpora lutea in anoestrous ewes. J. Reprod. Fert. 76, 349-363.

Imakawa, K., Anthony, R.V., Kazemi, M., Marotti, K.R., Polites, H.G. \& Roberts, R.M. (1987) Interferon-like sequence of ovine trophoblast protein secreted by embryonic trophectoderm. Nature, Lond. 330, 377379.

Ivell, R., Brackett, K.H., Fields, M.J. \& Richter, D. (1985) Ovulation triggers oxytocin gene expression in the bovine ovary. FEBS Lett. 190, 263-267.

Jones, D.S.C. \& Flint, A.P.F. (1988) Concentrations of oxytocin-neurophysin prohormone mRNA in corpora lutea of sheep during the oestrous cycle and in early pregnancy. J. Endocr. 117, 409414.

Kotwica, J., Schams, D., Meyer, H.H.D. \& Mittermeier, Th. (1988) Effect of continuous infusion of oxytocin on length of the oestrous cycle and luteolysis in cattle. J. Reprod. Fert. 83, 287-294.

Lamming, G.E., Darwash, A.O. \& Back, H.L. (1989) Corpus luteum function in dairy cows and embryo mortality. J. Reprod. Fert., Suppl. 37, 245-252.

Lowry, O.H., Rosebrough, N.J., Farr, A.L. \& Randall, R.J. (1951) Protein measurement with the Folin phenol reagent. J. biol. Chem. 193, 265-275.
McCracken, J.A., Schramm, W. \& Okulicz, W. (1984) Hormone receptor control of pulsatile secretion of PGF- $2 \alpha$ from the ovine uterus during luteolysis and its abrogation in early pregnancy. Anim. Reprod. Sci. 7, 31-55.

Meyer, H.H.D., Mittermeier, Th. \& Schams, D. (1988) Dynamics of oxytocin, estrogen and progestin receptors in the bovine endometrium during the estrous cycle. Acta endocr., Copenh. 118, 96-104.

Nissenson, R., Flouret, G. \& Hechter, O. (1978) Opposing effects of estradiol and progesterone on oxytocin receptors in rabbit uterus. Proc. natn. Acad. Sci. USA 75, $2044-2048$.

Oyedipe, E.O., Gustafsson, B. \& Kindahl, H. (1984) Blood levels of progesterone and 15-keto-13,14dihydroprostaglandin F $2 \alpha$ during the oestrous cycle of oxytocin treated cows. Theriogenology 22, 329 . 339.

Parkinson, T.J. \& Lamming, G.E. (1990) Interrelationships between progesterone, 13,14-dihydro-15 keto PGF-2 $\alpha$ (PGFM) and LH in cyclic and early pregnant cows. J. Reprod. Fert. 90, 221-233.

Parkinson, T.J., Jenner, L.J. \& Lamming, G.E. (1990) Comparison of oxytocin/PGF- $2 \alpha$ interrelationships in cyclic and pregnant cows. $J$. Reprod. Fert. 90, 337345.

Pliska, V., Heiniger, J., Muller-Lhotsky, A. \& Ekberg, B.A. (1984) Oxytocin receptors in sheep and rat myometrium: high or low affinity binding sites? J. Steroid Biochem. 20, 1505 , Abstr. Fl4.

Roberts, J.S., McCracken, J.A., Gavagan, J.E. \& Solofi, M.S. (1976) Oxytocin-stimulated release of prostaglandin F2 $\alpha$ from ovine endometrium in-vitro; correlation with estrous cycle and oxytocin-receptor binding. Endocrinology 99, 1107-1114.

Scatchard, G. (1949) The attractions of proteins for small molecules and ions. Annls NY Acad. Sci. 51, 660-672.

Schams, D. (1987) Luteal peptides and intercellular communication. J. Reprod. Fert., Suppl. 34, 87-99.

Schams, D. \& Lahlou-Kassi, A. (1984) Circulating concentrations of oxytocin during pregnancy in ewes. Acta endocr., Copenh. 106, 277-281.

Schams, D., Schallenberger, E., Meyer, H.H.D., Bullerman, B., Breitinger, H-J., Enzenhoffer, G., Koll, R., Kruip, T.A.M., Walter, D.L. \& Karg, H. (1985) Ovarian oxytocin during the estrous cycle in cattle. In Oxytocin, Clinical and Laboratory Studies, pp. 317334. Eds J. A. Amico \& A. G. Robinson. Elsevier Sci. Publ., Amsterdam.

Sheldrick, E.L. \& Flint, A.P.F. (1983) Luteal concentrations of oxytocin decline during early pregnancy in the ewe. J. Reprod. Fert. 68, 477-480.

Sheldrick, E.L. \& Flint, A.P.F. (1985) Endocrine control of uterine oxytocin receptors in the ewe. $J$. Endocr. 106, 249-260.

Sheldrick, E.L. \& Flint, A.P.F. (1987) Effect of continuous oxytocin infusion on prostaglandin-F2 $\alpha$ secretion in the cyclic ewe. J. Endocr., Suppl. 115, Abstr. 36.

Soloff, M.S. (1975) Uterine receptor for oxytocin: effects of estrogen. Biochem. Biophys. Res. Commun. 65, $205-212$.

Soloff, M.S. \& Fields, M.J. (1989) Changes in uterine oxytocin receptor concentrations throughout the estrous cycle of the cow. Biol. Reprod. 40, 283-287. 
Soloff, M.S. \& Swartz, T.L. (1974) Characterization of a proposed oxytocin receptor in the uterus of the rat and sow. J. biol. Chem. 249, 1376-1381.

Stewart, H.J., McCann, S.H.E., Barker, P.J., Lee, K.E., Lamming, G.E. \& Flint, A.P.F. (1987) Interferon sequence homology and receptor binding activity of ovine trophoblast antiluteolytic protein. $J$. Endocr. 115, R13-R15.

Stewart, H.J., Flint, A.P.F., Lamming, G.E., McCann, S.H.E. \& Parkinson, T.J. (1989) Antiluteolytic effects of blastocyst-secreted interferon investigated in vitro and in vivo in the sheep. J. Reprod. Fert., Suppl. 37, 127-138.

Vallet, J.L., Bazer, F.W., Fliss, M.F.V. \& Thatcher, W.W. (1988) Effect of ovine conceptus secretory proteins and purified ovine trophoblast protein-1 on interoestrus interval and plasma concentrations of prostaglandins F-2 $\alpha$ and $\mathrm{E}$ and of 13,14-dihydro-15keto prostaglandin F-2 $\alpha$ in cyclic ewes. $J$. Reprod. Fert. 84, 493-504.

Vallet, J.L., Lamming, G.E \& Batten, M. (1990) Control of endometrial oxytocin by progesterone and oestradiol in the ewe. J. Reprod. Fert. 90, 625-634.

Wathes, D.C., Swann, R.W. \& Pickering, B.T. (1984) Variations in oxytocin, vasopressin and neurophysin concentrations in the bovine ovary during the oestrous cycle and pregnancy. J. Reprod. Fert. 71, 551557.

Received 23 February 1990 